\title{
DIVERSIFIKASI KONSUMSI PANGAN BERBASIS POTENSI LOKAL KOTA TARAKAN
}

\section{DIVERSIFICATION OF FOOD CONSUMPTION BASED ON LOCAL POTENTIAL OF TARAKAN CITY}

\author{
Galih Yogi Rahajeng1), Khotimah2), \\ 1) Dosen Fakultas Pertanian, Jurusan Agribisnis, Universitas Borneo Tarakan \\ 2) Mahasiswa Fakultas Pertanian, Jurusan Agribisnis, Universitas Borneo Tarakan \\ Email: ${ }^{1}$ galihyogirahajeng@gmail.com
}

\begin{abstract}
ABSTRAK
Diversifikasi konsumsi pangan akan memberikan manfaat yang besar, apabila mampu menggali dan mengembangkan potensi sumber-sumber pangan lokal. Namun diversifikasi pangan pokok atau pangan sumber karbohidrat yang banyak dikonsumsi oleh masyarakat di Kota Tarakan, masih memiliki pola pangan pokok yang kearah tunggal yaitu beras. Oleh karena itu, kajian terkait diversifikasi pangan non beras berbasis pangan lokal perlu dilakukan. Adapun tujuan khusus adalah menganalisis potensi sumber daya pangan lokal di Kota Tarakan, menganalisis pola konsumsi pangan dan tingkat diversifikasi pangan rumah tangga Di Kota Tarakan. Penelitian ini menggunakan teknik survey dengan sampel rumah tangga di empat kecamatan di Kota Tarakan dengan teknik pengambilan sampel yang digunakan adalah teknik nonprobality sampling dengan metode quota sampling. Metode analisis data yang digunakan adalah analisis deskriptif kuantitatif dan household dietry diversity score (HDDS). Hasil analisis menunjukkan produksi padi di Kota Tarakan cenderung mengalami penurunan, sedangkan produksi ubi kayu dan ubi jalar menunjukkan tren meningkat yang mengindikasi potensi diversifikasi produksi pangan di Kota tarakan. Secara garis besar pola diversifikasi konsumsi pangan masyarakat di Kota Tarakan cukup beragam berdasarkan jumlah, kualitas dan variannya, hal ini ditunjukkan dari pengeluaran pangan sumber protein yang beragam. Namun diversifikasi pangan sumber karbohidrat yang perlu dikaji karena masih tingginya pengeluaran akan sumber karbohidrat beras. Tingkat diversifikasi konsumsi pangan di Kota Tarakan berdasarkan nilai skor keragaman pangan rumah tangga (HDDS) berada pada kategori tinggi yaitu telah mengkonsumsi lebih dari enam jenis sumber pangan dalam sehari.
\end{abstract}

Kata kunci : Diversifikasi, Konsumsi, Pangan, Rumah tangga.

\begin{abstract}
Diversification of food consumption will provide great benefits, if it is able to explore and develop potential local food sources. Howeer, the diersification of staple food or food sources of carbohydrates which are widely consumed by the people in Tarakan City, still hae a single staple food pattern, namely rice. Therefore, a study related to the diversification of non-rice food based on local food needs to be carried out. The specific objectives are to analyze the potential of local food resources in Tarakan City, to analyze food consumption patterns and the level of household food diversification in Tarakan City. ResearchThis technique uses a survey technique with a sample of households in four districts in the City of Tarakan with the sampling technique used is nonprobality sampling technique with quota sampling method. The data analysis method used is quantitative descriptive analysis and household dietry diversity score (HDDS). The analysis result shows rice production in Tarakan City tends to decline, while the production of cassava and sweet potato shows an increasing trend which indicates the potential for diversification of food production in Tarakan City. Broadly speaking, the pattern of diversification of people's food consumption in Tarakan City is quite diverse based on the amount, quality and variant, this is shown from the expenditure of various protein sources. However, the diversification of food sources of carbohydrates needs to be studied because of the high expenditure on carbohydrate sources for rice. The level of diversification of food consumption in Tarakan City based on the value of the household food diversity score (HDDS) is in the high category, namely having consumed more than six types of food sources in a day.
\end{abstract}

Keywords : Consumption, Diersification, Food Household 
JURNAL BORNEO SAINTEK

Volume 1, Nomor 1, April 2020

e-ISSN 2599-3313

P-ISSN 2615-434X

\section{PENDAHULUAN}

Pemerintah telah berkomitmen dalam mewujudkan ketahanan pangan nasional yang tertumpu pada kemandirian dan kedaulatan pangan dalam rangka pembangunan ekonomi dan pertanian domestik. Pilar ketahanan pangan dibangun berdasarkan sumber daya, kelembagaan, dan budaya lokal yang bertujuan untuk meningkatkan keanekaragaman dalam produksi dan konsumsi pangan lokal yang bergizi dan aman untuk dikonsumsi oleh masyarakat.

Pemerintah menetapkan kebijakan yang ditindaklanjuti dengan Gerakan Percepatan Penganekaragaman Konsumsi Pangan berbasis Sumberdaya Lokal oleh Kementerian Pertanian dengan target terjadi penurunan konsumsi beras sebesar 1,5\%/tahun dan kenaikan skor Pola Pangan Harapan (PPH) sebesar 1 /tahun. Hal ini berarti pola pangan masyarakat Indonesia harus berdiversifikasi tidak hanya pangan pokok yang bertumpu pada beras tetapi juga diversifikasi pangan secara luas. Potensi pangan lokal sumber karbohidrat di Indonesia telah banyak dan beragam jenisnya seperti jagung, ubikayu, ubijalar, sagu, adung, gembili, pisang, sukun, talas dan lain-lain. Komoditas pangan ini dapat dikembangkan sebagai upaya mempercepat diversifikasi konsumsi pangan. (Ariani et al., 2013)

Pelaksanaan diversifikasi konsumsi pangan menuju konsumsi pangan yang beragam, bergizi, seimbang, dan aman akan memberikan manfaat yang besar, apabila mampu menggali dan mengembangkan potensi sumber-sumber pangan lokal. Namun diversifikasi pangan pokok atau pangan sumber karbohidrat yang banyak dikonsumsi oleh masyarakat di Kota Tarakan, masih sukar dilaksanakan yang ditunjukkan dengan masih tingginya konsumsi beras dan pola pangan pokok yang kearah tunggal yaitu beras. Sejak lama Indonesia mempunyai pola pangan pokok yang beragam dengan menggunakan pangan lokal non beras seperti jagung, aneka umbiumbian, pisang dan sagu, begitu juga dengan potensi pangan pokok di Kota Tarakan telah banyak dan beragam jenisnya. Data BPS 2019 menjadi salah satu indikator potensi diverisfikasi di Kota Tarakan yaitu pada tahun 2018, di Kota Tarakan hanya terdapat padi sawah dengan luas panen seluas 63 hektar. Padi sawah tersebut tersebar di dua kecamatan, yaitu 58 hektar luas panen berada di Kecamatan Tarakan Timur dan 5 hektar luas panen di Kecamatan Tarakan
Available online at www.jurnal.borneo.ac.id

Halaman 63-72
Utara. Selain itu terdapat beberapa jenis sayursayuran yang menjadi komoditas utama yang diproduksi di Kota Tarakan. Sayur-sayuran tersebut antara lain: kacang panjang, cabai, kangkung, bayam, dan petsai. Di antara kelima jenis sayur-sayuran tersebut, cabai merupakan jenis sayuran dengan luas panen terluas di Kota Tarakan tahun 2018, yaitu 321 hektar. Jika dilihat di masing-masing kecamatan, 17,13 persen berada di Kecamatan Tarakan Timur, 19,94 persen di Kecamatan Tarakan Tengah, 23,99 persen di Kecamatan Tarakan Barat, dan 38,94 persen luas panen cabai berada di Kecamatan Tarakan Utara. Untuk tanaman palawija, pada tahun 2018 luas panen ubi kayu di Kota Tarakan adalah 175 hektar. Berdasarkan kecamatan, sebesar 15,43 persen berada di Kecamatan Tarakan Timur, 21,14 persen di Kecamatan Tarakan Tengah, 27,43 persen di Kecamatan Tarakan Barat, dan 63,00 persen luas panen ubi kayu berada di Kecamatan Tarakan Utara. Berdasarkan data BPS 2018 Kota Tarakan mampu memproduksi daging sapi 271 ton dan daging ayam 4.597 ton pada tahun 2017, sedangkan sektor perikanan mampu menghasilkan produksi hingga 238.377 ton. (BPS, 2019)

Berdasarkan kondisi wilayah dan potensi sumber daya alam yang ada di Kota Tarakan, memungkinkan hampir semua komoditi dari usaha tani dapat dibudidayakan dan dikembangkan. Potensi ini tentu saja akan menjadi sumber-sumber pangan lokal yang mendukung diversifikasi pangan, namun seringkali pemerintah hanya menganjurkan masyarakat untuk melakukan keanekaragaman konsumsi pangan dan bersifat hanya menyuruh tanpa didukung oleh ketersediaan bahannya yang dapat diperoleh secara mudah. Oleh karena itu, kajian terkait diversifikasi pangan non beras berbasis pangan lokal perlu dilakukan. Peran pangan non beras ini dapat sebagai pangan pokok atau pangan selingan. Pangan lokal yang dimaksud adalah pangan sumber karbohidrat (umbi-umbian, jagung, sagu, dll), sayur-sayuran dan sumber protein yang dikonsumsi dan diproduksi berbasis potensi dan kearifan lokal. Secara umum tujuan dari kajian ini adalah untuk menganalisis pengembangan diversifikasi pangan berbasis pangan lokal. Adapun tujuan khusus adalah menganalisis potensi sumber daya pangan lokal di Kota Tarakan dan menganalisis pola konsumsi pangan dan tingkat 
diversifikasi pangan rumah tangga $\mathrm{Di}$ Kota Tarakan.

\section{METODOLOGI PENELITIAN}

Penelitian dilaksanakan di empat kecamatan di kota Tarakan yaitu Tarakan barat, Tarakan timur, Tarakan utara dan Tarakan tengah. Teknik pengambilan sampel yang digunakan adalah teknik nonprobality sampling dengan metode quota. Jenis data yang dikumpulkan dalam penelitian ini meliputi data primer dan data sekunder. Data primer dikumpulkan melalui Indepth interview (wawancara secara mendalam) menggunakan kuesioner survey pangan berupa food recall 24 jam untuk mendapatkan data pola konsumsi pangan, Skor keragaman konsumsi rumah tangga (Household Dietry Diversity Score) . Data sekunder diperoleh dari instansi terkait dengan ketahanan pangan dan studi pustaka yang relevan diantaranya data potensi (lahan) dan perkembangan luas panen, produksi dan produktivitas pangan lokal. Rumusan masalah pertama dianalisis menggunakan analisis deskriptif kualintatif dengan menjabarkan datadata yang telah dikumpulkan. Rumusan masalah kedua menganalisis diversifikasi konsumsi pangan lokal di Kota Tarakan Salah satu metode yang dikembangkan oleh Food and Agriculture Organizations (FAO) untuk menilai kualitas konsumsi pangan ditingkat rumah tangga adalah Household Dietary Diversity Score (HDDS) (Swindale A, 2005) Metode ini menggambarkan kemampuan akses rumah tangga terhadap berbagai jenis pangan. Pengumpulan data konsumsi pangan rumah tangga dengan metode HDDS dilakukan menggunakan kuesioner recall $1 \times 24$ jam. Menurut (Savy M, Prevel YM, Sawadogo P, Kameli Y, 2005), food recall $1 \times 24$ jam dapat digunakan pada penilaian kualitas konsumsi pangan ditingkat populasi dan bermanfaat untuk memantau program atau target suatu intervensi. Pertimbangan FAO menggunakan recall $1 \times 24$ jam untuk menilai kualitas konsumsi pangan rumah tangga dengan metode HDDS adalah untuk mengurangi kesalahan dalam pengukuran, lebih praktis, dan penggunaan waktu $1 \times 24$ jam ini umum digunakan dalam penelitian kualitas konsumsi pangan seperti yang dilakukan oleh (Savy M, Prevel YM, Sawadogo P, Kameli Y, 2005); Steyn et al. (2006)(Styen NP, Nel JH, Nantel G, Kennedy G, 2006);(Arimond, 2010); (Melani, 2014); (Rahajeng, 2015). Berdasarkan pertimbangan tersebut, periode food recall $1 \mathrm{x}$ 24 jam digunakan dalam penilaian diversifikasi konsumsi pangan rumah tangga. Pada perhitungan skor HDDS, jenis pangan yang dikonsumsi rumah tangga dikelompokkan ke dalam 12 kelompok pangan yaitu serealia, umbiumbian, sayuran, buah-buahan, daging dan olahannya, telur, ikan, kacang-kacangan, susu, minyak, pemanis, bumbu. Selanjutnya pemberian skor dilakukan dengan memberikan skor 1 jika rumah tangga mengonsumsi salah satu jenis pangan yang terdapat dalam kelompok pangan dan skor 0 jika tidak mengonsumsi salah satu jenis pangan yang terdapat dalam kelompok pangan yang sudah ditetapkan oleh FAO. Keragaman konsumsi pangan berdasarkan HDDS dikelompokkan ke dalam tiga kategori yaitu rendah jika konsumsi $\leq 3$ jenis bahan pangan, sedang jika konsumsi 4-5 jenis bahan pangan, dan tinggi jika konsumsi $\geq 6$ jenis bahan pangan (FAO, 2013).

\section{HASIL DAN PEMBAHASAN Potensi Pangan Kota Tarakan}

Peraturan Presiden No.22 tentang Kebijakan Percepatan Penganekaragaman Konsumsi Pangan Berbasis Sumber Daya Lokal, bahwa upaya penganekaragaman konsumsi pangan harus berbasis sumber pangan setempat atau pangan lokal. Pangan lokal sumber karbohdrat yang berpeluang untuk dikembangkan di Tarakan antara lain Padi, Ubi Kayu dan Ubi Jalar.

\section{a. Padi-Padian}

Padi, yang kemudian diolah menjadi beras, merupakan sumber utama kalori bagi sebagian besar penduduk Indonesia. Oleh karena itu, produksi padi sangat menentukan bagi ketersediaan pangan pokok bagi penduduk Indonesia yang saat ini bejumlah lebih dari 244 juta jiwa. Perkembangan produksi padi di Indonesia menunjukkan trend yang masih meningkat kondisi ini dalam jangka panjang akan menjaga kemandirian dalam penyediaan beras nasional secara berkelanjutan. Permasalahannya adalah bahwa pengembangan padi sawah memerlukan sarana irigasi untuk menjamin ketersediaan air bagi tanaman padi, sedangkan di Pulau Kalimantan ketersediaan sarana irigasi relatif terbatas. Di samping itu, ada juga permasalahan yang terkait dengan konektivitas antara daerah sentra produksi dan sentra konsumsi padi, sehingga perlu dilakukan pembangunan infrasrtuktur jalan, jembatan, 
pelabuhan, serta sarana transportasi dan sarana logistik di pulau Kalimantan. (Ariani et al., 2013). Oleh karena itu produksi padi tidak mampu memenuhi kebutuhan pangan di Kalimantan. Kalimantan Utara yang berada di perbatasan memiliki masalah ganda yaitu irigasi dan konektivitas antara daerah sentra produksi dan sentra konsumsi padi, sehingga menyebabkan harga beras cenderung mahal. Menurut (Harini et al., 2019) Secara umum produksi padi di Provinsi Kalimantan Utara mengalami penurunan produksi. Daerah penghasil padi paling banyak terdapat di Kabupaten Bulungan, kemudian Kabupaten Nunukan dan selanjutnya adalah Kabupaten Malinau, sementara itu untuk Kabupaten Tana Tidung dan Kota Tarakan produksi padi hanya sedikit. Potensi produksi padi di Kota Tarakan dari tahun 2010 - 2019 mengalami tren penurunan dari tahun ketahun. Hal ini dikarenakan petani beralih menanam komodi lain seperti sayuran, jagung manis dan ubi kayu yang lebih mahal harga jualnya dan lebih mudah proses perawatannya. Hal ini menjadi indikator apabila ditangani lebih lanjut Kota Tarakan berpotensi dalam produksi padi dan pemenuhan kebutuhan pangan mandiri.

\section{b. Ubi Kayu}

Sebagian masyarakat Indonesia menggolongkan ubi kayu sebagai secondary corps atau komoditi kelas dua. Padahal, tanaman yang nama latinnya Manihot utilissima ini memiliki kadar karbohidrat yang lebih tinggi dengan nasi putih. Ubi Kayu dibandingkan dengan kelompok pangan lokal sumber karbohidrat non beras lainnya, lebih banyak dikenal, dibudidayakan dan diolah hasilnya untuk pemenuhan pangan pokok maupun kudapan. Teknik budidaya yang mudah dan murah menjadi pertimbangan utama banyak petani di Kota Tarakan memilih tanaman ini dibandingkan jenis umbi atau yang lainnya. Terlebih lagi banyak wilayah di Kota Tarakan yang termasuk kategori lahan marginal atau lahan kering, sehingga ubi kayu sangat sesuai untuk dibudidayakan baik skala rumah tangga maupun pada lahan yang luas.

Berdasarkan data BPS walaupun terjadi kecenderungan semakin berkurangnya lahan produksi, tetapi tingkat produktivitasnya mengalami kenaikan. Hal ini mengisyaratkan bahwa petani pembudidaya ubikayu sudah mengarah pada usaha-usaha intensifikasi, yang bertujuan untuk meningkatkan hasil dan produktivitasnya. Dengan kondisi yang seperti ini maka kebutuhan ubikayu pada tingkat konsumen rumah tangga dapat terpenuhi.

\section{c. Ubi Jalar}

Ubi jalar atau sweet potato (Ipomea batatas) selain sebagai sumber karbohidrat juga digunakan sebagai bahan baku industri, pakan dan komoditas ekspor. Sebagai sumber karbohidrat, ubi jalar berpeluang dalam program diversifikasi pangan dan peningkatan gizi masyarakat. Secara nasional produksi ubi jalar mengalami peningkatan dari tahun ketahun Untuk meningkatkan produktivitas ubi jalar dapat dilakukan dengan penerapan teknologi budidaya dan pasca panen yang dianjurkan berdasarkan hasil penelitian. Pemanfaatan ubi jalar khususnya di Kota Tarakan masih terbatas pada pengolahan ubi segar menjadi penganan secara tradisional, direbus, digoreng maupun campuran dalam makanan seperti kue .

Pada tingkat Nasional berbeda dengan padi dan jagung, pengembangan ubi kayu dan ubi jalar di Indonesia boleh dikatakan tidak didukung oleh kebijakan dan program pemerintah. Hal tersebut menyebabkan petani kurang mempunyai insentif untuk menanam ubi kayu dan ubi jalar. Bahkan data secara tidak langsung menunjukkan adanya kecenderungan bagi petani untuk beralih dari menanam ubi kayu dan ubi jalar, dan menggantikannya dengan dengan menanam padi atau jagung. Jika hal ini berjalan secara berkelanjutan, maka dikhawatirkan bahwa diversifikasi produksi pangan nasional akan berkurang, dan hal ini dalam jangka menengah, ataupun jangka panjang akan menimbulkan kerentanan bagi system produksi pangan nasional.(Ariani et al., 2013). Namun di Kota Tarakan, adanya kecenderungan petani beralih dari menanam padi dan menggantikannya dengan sumber karbohidrat lainnya seperti ubi kayu dan ubi jalar. Hal ini merupakan potensi dalam diersifikasi produksi pangan, namun yang menjadi kendala adalah pola konsumsi masyarakat yang masih mengutamakan beras sebagai sumber karbohidrat sedangkan ubi kayu dan ubi jalar sebagai makanan selingan saja.

\section{Pola Konsumsi Pangan Rumah Tangga di Kota Tarakan \\ a. Hubungan Karakteristik Rumah Tangga Dengan Diersifikasi Konsumsi Pangan}


JURNAL BORNEO SAINTEK

Volume 1, Nomor 1, April 2020

e-ISSN 2599-3313

P-ISSN 2615-434X

Karakteristik responden dalam penelitian ini diuraikan berdasarkan usia, tingkat pendidikan jumlah anggota rumah tangga, pekerjaan, dan pendapatan rumah tangga. Jumlah responden seluruhnya adalah 60 ibu rumah tangga (Tabel 1.).

Tabel 1. Karakteristik Responden

\begin{tabular}{lrr}
\hline \multicolumn{1}{c}{ Variable } & $\mathrm{n}$ & \multicolumn{1}{c}{$\%$} \\
\hline Jumlah Anggota Keluarga & & \\
\hline 2 & 10 & $17 \%$ \\
3 & 7 & $12 \%$ \\
4 & 19 & $32 \%$ \\
5 & 15 & $25 \%$ \\
$\geq 6$ & 9 & $15 \%$ \\
\hline Total & 60 & $100 \%$ \\
\hline \hline Pendidikan & & \\
\hline SD & 12 & $20 \%$ \\
SMP & 5 & $8 \%$ \\
SMA & 25 & $42 \%$ \\
D3 & 5 & $8 \%$ \\
S1 & 13 & $22 \%$ \\
\hline Total & 60 & $100 \%$ \\
\hline \hline Pekerjaan & & \\
\hline Wiraswasta & 20 & $33 \%$ \\
IRT & 17 & $28 \%$ \\
Karyawan & 11 & $18 \%$ \\
Buruh & 6 & $10 \%$ \\
Petani & 1 & $2 \%$ \\
PNS & 5 & $8 \%$ \\
\hline Total & 60 & $100 \%$ \\
\hline \hline Pendapatan Rumah Tangga & & \\
\hline S 1.000.000 & 10 & $17 \%$ \\
1.000.001 - 2.000.000 & 18 & $30 \%$ \\
2.000.001 - 3.000.000 & 19 & $32 \%$ \\
3.000.001 - 4.000.000 & 0 & $0 \%$ \\
$\geq 5.000 .000$ & 6 & $10 \%$ \\
\hline Total & 7 & $12 \%$ \\
\hline S.000.000 & 60 & $100 \%$ \\
\hline
\end{tabular}

Sumber : Data Penelitian Diolah 2020

Berdasarkan tabel 1, jumlah anggota keluarga terbanyak yaitu 4 orang dengan proporsi $32 \%$ dari keseluruhan responden dengan komposisi mayoritas Ayah (kepala Keluarga), Ibu dan 2 anak. Proporsi kedua adalah responden dengan jumlah keluarga 5 orang yaitu $25 \%$, hal ini dapat disimpulkan mayoritas responden memiliki jumlah anggota keluarga yang tergolong besar. Besarnya jumlah anggota keluarga merupakan salah satu faktor
Available online at www.jurnal.borneo.ac.id Halaman 63-72

yang mempengaruhi pola konsumsi rumah tangga. Banyaknya anggota keluarga, maka pola konsumsinya semakin beragam karena masingmasing anggota rumah tangga belum tentu mempunyai selera yang sama.

Tingkat pendidikan orang tua merupakan salah satu faktor yang berpengaruh terhadap pola asuh anak termasuk dalam hal konsumsi pangan. Latar belakang pendidikan ibu juga dianggap erat kaitannya dengan keragaman dan komposisi 4 sehat 5 sempurna dalam pangan sehari-hari keluarga yang berperan penting dalam menentukan status gizi keluarga. Hal ini dikarenakan ibu yang memiliki tingkat pendidikan yang tinggi dianggap memiliki pengetahuan yang lebih baik dalam hal kebutuhan gizi. Berdasarkan hasil penelitian $42 \%$ responden jenjang pendidikan terakhir adalah SMA dan $22 \%$ pada jenjang pendidikan $\mathrm{S} 1$, hal ini menjadi tanda positif akan tingginya tingkat pengetahuan ibu rumah tangga akan pengetahuan gizi dan pentingnya keragaman pangan.

Ibu sebagai responden dalam penelitian $33 \%$ bekerja sebagai wiraswasta (berdagang barang maupun jasa), $38 \%$ bekerja di berbagai bidang lainnya dan hanya $28 \%$ sebagai ibu rumah tangga. Ibu bekerja dianggap tidak memiliki waktu yang cukup untuk menyiapkan pangan yang beragam bagi keluarga dibandingkan ibu rumah-tangga namun ibu bekerja memiliki kontribusi dalam pendapatan keluarga yang tentu saja akan mempengaruhi pengeluaran rumah tangga.

Pendapatan merupakan salah satu yang memengaruhi diversifikasi pangan rumah tangga. Makin tinggi pendapatan rumah tangga, makin terdiversifikasi pangan yang dikonsumsi rumah tangga tersebut. Sebaliknya, rumah tangga yang memiliki pendapatan rendah hanya akan mengonsumsi produk pangan tertentu saja, terutama komoditas beras. Selain itu, faktor harga pangan memengaruhi permintaan rumah tangga terhadap jenis pangan tertentu, yang kemudian akan memengaruhi permintaan konsumsi pangan rumah tangga. Peningkatan pendapatan mengakibatkan peningkatkan kualitas konsumsi pangan. Pada tingkat pendapatan yang lebih rendah, permintaan pangan lebih diutamakan pada beras. Apabila pendapatan meningkat, maka pola konsumsi pangan akan lebih beragam serta umumnya akan terjadi peningkatan konsumsi pangan yang lebih bernilai gizi tinggi. Jika pendapatan yang 
diperoleh tidak mencukupi untuk membeli bahan pangan, maka risiko untuk menjadi rawan pangan menjadi semakin tinggi. Kenaikan tingkat pendapatan per orang, akan menyebabkan perubahan dalam susunan pangan yang dikonsumsi.(Saputri et al., 2016). Berdasarkan Tabel 1, mayoritas responden atau $32 \%$ memiliki pendapatan pada kategori Rp. 2.000 .001 - Rp. 3.000.000 dan $22 \%$ pada kategori pendapatan diatas Rp. 3.000.000, hal ini berarti lebih dari $50 \%$ responden memiliki pendapatan di atas UMR Kota Tarakan.

b. Pengeluaran Pangan

Ada dua cara pemanfaatan pendapatan. Pertama, membelanjakannya untuk barangbarang konsumsi. Kedua, tidak membelanjakannya seperti ditabung. Pengeluaran rumah tangga terdiri atas dua kelompok, yaitu pengeluaran untuk makanan dan bukan makanan. Pada kondisi pendapatan terbatas, kebutuhan makanan didahulukan, sehingga pada kelompok masyarakat berpendapatan rendah akan terlihat bahwa sebagian besar pendapatannya digunakan untuk membeli makanan. Seiring dengan peningkatan pendapatan, maka lambat laun akan terjadi pergeseran pola pengeluaran, pengeluaran untuk pangan yang lebih banyak tidak menjamin lebih beragamnya konsumsi pangan. Kadangkadang perubahan utama yang terjadi dalam kebiasaan makanan adalah pangan yang dikonsumsi lebih mahal harganya(Saputri et al., 2016). Hal ini sejalan dengan teori Maslow yang menyatakan bahwa manusia termotivasi untuk memenuhi kebutuhan hidupnya. Kebutuhan tersebut memiliki tingkatan mulai dari yang paling rendah bersifat fisiologis seperti makan, sampai yang paling tinggi berupa aktualisasi diri Pengeluaran rumah tangga merupakan salah satu indikator yang dapat memberikan gambaran keadaan kesejahteraan penduduk serta mencerminkan pendapatan keluarga. Hukum Engle menyatakan jika selera tidak berbeda maka persentase pengeluaran untuk makanan akan menurun dengan meningkatnya pendapatan.(SUSENAS, 2019)

Data SUSENAS 2019 menunjukkan bahwa rata-rata setiap penduduk Indonesia mengeluarkan sebesar 1.205 .862 rupiah setiap bulan untuk kebutuhan baik makanan maupun bukan makanan. Dalam sebulan, rata-rata pengeluaran per kapita komoditas bukan makanan sebesar 612.412 rupiah atau 50,79 persen dari total pengeluaran. Di sisi lain, pengeluaran yang digunakan untuk memenuhi kebutuhan makanan sebesar 593.450 rupiah. Rata rata pengeluaran masyarakat Kalimantan Utara adalah Rp. 1.565.255 dengan besaran pengeluaran pangan yaitu Rp. 804.422 dan pengeluaran non pangan Rp. 760.834. Hal ini mengindikasikan pada umumnya masyarakat kalimantan utara pangsa pengeluaran pangan lebih tinggi dibandingkan non pangan. Berdasarkan hasil penelitian yang terangkum pada gambar 2. masyarakat kota Tarakan juga memiliki kecenderungan pengeluaran pangan yang tinggi yaitu 33\% pada kelompok pengeluaran pangan Rp. 1.000.000-Rp. 1.500 .000 lebih tinggi dibandingkan rata-rata pengeluaran pangan masyarakat Kalimantan Utara berdasarkan data SUSENAS. Tingginya pengeluaran akan pangan di Kota Tarakan, menjadi salah satu indikator akan ketahanan pangan dan diersifikasi pangan yang dikonsumsi masyarakat Kota Tarakan pada Umumnya.

\section{Kelompok Pengeluaran \\ Pangan di Kota Tarakan}

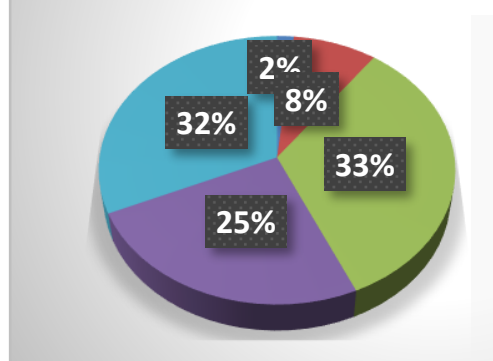

$$
\begin{aligned}
& \leq \text { Rp. } 500.000 \\
& \text { Rp. } 500.001 \text { - Rp. } \\
& \text { 1.000.000 } \\
& \text { Rp. } 1.000 .001 \text { - Rp. } \\
& \text { 1.500.000 } \\
& \text { Rp. } 1.500 .001 \text { - Rp. } \\
& \text { 2.000.000 } \\
& \geq \text { Rp. } 2.000 .000
\end{aligned}
$$

\section{Gambar 1. Diagram Pie Kelompok Pengeluaran Pangan Kota Tarakan 2020}

\section{Pengeluaran Pangan Berdasarkan Kelompok Pangan}

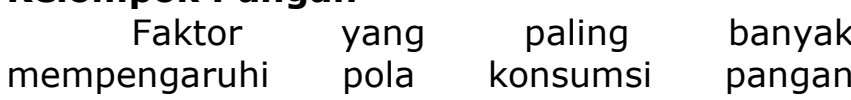
masyarakat adalah faktor ekonomi yang juga erat kaitannya dengan daya beli masyarakat. Status ekonomi seseorang menunjukkan daya beli masyarakat terhadap produk pangan dalam pemenuhan kebutuhan gizi sehari-hari. Pada masyarakat tingkat ekonomin tinggi, akan dapat memenuhi semua kebutuhan pangan yang diperlukan oleh tubuhnya yang cenderung beragam dan memiliki protein tinggi (makanan dari sumber hewani). Pada masyarakat tingkat ekonomi rendah, pengeluaran mereka akan pangan cenderung kurang sehingga pola makan 
JURNAL BORNEO SAINTEK

Volume 1, Nomor 1, April 2020

e-ISSN 2599-3313

P-ISSN 2615-434X

menjadi terbatas dan cenderung makanan yang dikonsumsi sama dan berulang setiap harinya, dalam artian tidak beragam. Apabila secara kuantitas kebutuhan pangan sudah terpenuhi, maka lazimnya rumah tangga akan mementingkan kualitas atau beralih pada pengeluaran non pangan. Dengan demikian, terdapat kecenderungan semakin tinggi pendapatan seseorang semakin berkurang pengeluaran akan pangan. Oleh karena itu, komposisi pengeluaran rumah tangga dapat dijadikan ukuran guna menilai tingkat kesejahteraan ekonomi. (Saputri et al., 2016)

Tabel 2. Rata-rata Pengeluaran Pangan Berdasarkan Kelompok Pangan di Kota Tarakan 2020

\begin{tabular}{lrr}
\hline \multicolumn{1}{c}{$\begin{array}{c}\text { Kelompok } \\
\text { Pangan }\end{array}$} & $\begin{array}{c}\text { Rata-rata } \\
\text { Pengeluaran } \\
\text { Pangan } \\
\text { (Rp/Bulan) }\end{array}$ & $\begin{array}{r}\text { Persentase } \\
(\%)\end{array}$ \\
\hline Beras & 203.707 & 14,0 \\
Umbi-umbian & 51.433 & 3,5 \\
Sayuran & 166.667 & 11,5 \\
Buah-Buahan & 97.433 & 6,7 \\
Daging & 158.680 & 10,9 \\
Telur & 64.120 & 4,4 \\
Ikan & 145.100 & 10,0 \\
Kacang-kacangan & 50.613 & 3,5 \\
Susu & 99.047 & 6,8 \\
Minyak & 61.260 & 4,2 \\
Bumbu & 81.140 & 5,6 \\
Pemanis & 43.447 & 3,0 \\
Makanan Jadi & 141.967 & 9,8 \\
Gandum & 62.407 & 4,3 \\
Sagu/Tapioka & 23.207 & 1,6 \\
\hline Total & 1.450 .227 & 100 \\
\hline Sumber : Data Penelitin &
\end{tabular}

Sumber : Data Penelitian Diolah 2020
Diversifikasi
pangan
adalah

mengkonsumsi lima kelompok makanan setiap hari atau setiap kali makan, ragam kelompok pangan yang terdiri dari bahan makanan pokok, lauk pauk, sayur dan buah serta air. Mengkonsumsi lebih dari satu jenis kelompok makanan setiap kali makan lebih baik. Berdasarkan tabel 2, pengeluaran rumah tangga responden di Kota Tarakan proporsi tertinggi adalah pengeluaran untuk beras yaitu 14 persen dari total pengeluaran makanan rumahtangga per bulan dengan rata-rata pengeluaran beras adalah Rp. 203.707 per rumah tangga per bulan. Posisi kedua pengeluaran untuk sayuran dengan proporsi 11,5 persen dari pengeluaran pangan rumahtangga perbulan dengan rata-rata pengeluaran belanja sayur yaitu Rp. 166.667 per
Available online at www.jurnal.borneo.ac.id

Halaman 63-72 rumah tangga per bulan selanjutnya masing masing 10 persen dari pengeluaran pangan rumahtangga perbulan untuk pengeluaran daging dan ikan. Hal ini berbeda dengan penelitian (Rahajeng, 2015) di Kota Palembang yang menyatakan Ikan sebagai proporsi pengeluaran terbesar dan yang kedua adalah beras. Perbedaan ini dikarenakan faktor Kota Tarakan merupakan sebuah kepualauan yang sumber pangan beras dan sayuran mayoritas berasal dari luar daerah sehingga harganya cenderung mahal sedangkan ikan atau beraneka jenis makanan laut yang melimpah dengan harga relative lebih murah.

Konsumsi karbohidrat di Kota Tarakan masih didominasi oleh beras dan komoditas karbohidrat lainnya hanya sebagai camilan. Tingginya dominasi nasi dalam makanan Indonesia saat ini salah satunya disebabkan kualitas konsumsi pangan nasional yang rendah, tidak variatif dan bergizi seimbang. Nasi sebagai makanan pokok sebagian besar masyarakat Indonesia, telah membudaya tidak hanya dalam pola konsumsi makanan, tetapi juga dinilai sudah lebih baik citra makanan dari sisi sosial. Rata-rata pengeluaran pangan beras di Kota Tarakan adalah Rp. 203.707 per rumah tangga per bulan lebih tinggi dibandingkan pengeluaran pangan nasional berdasarkan data SUSENAS hanya Rp. 64.995 per rumah tangga per bulan. Hal ini disebabkan harga beras dan komsumsi beras yang cenderung tinggi di Kota Tarakan. Sedangkan sumber karbohidrat selain beras yang mendominasi adalah gandum dengan proporsi 4,3 persen per rumah tangga per bulan, namun konsumsi sumber karbohidrat ini hanya sebagai makanan ringan seperti aneka kue dan gorengan.

Buah dan sayur merupakan unsur yang penting bagi makanan yang sehat. Manfaat konsumsi buah dan sayur setiap hari untuk kesehatan badan mengingat tingginya kandungan beragam vitamin dan mineral serta serat pada buah dan sayur. Jika dikonsumsi dengan porsi yang dianjurkan, konsumsi buah dan sayur dapat mengurangi risiko defisiensi gizi mikro dan serangan penyakit tidak menular. Kurangnya konsumsi buah dan sayur merupakan penyebab risiko ke-10 tertinggi dari angka kematian di dunia. konsumsi buah dan sayur penduduk Indonesia belum memadai. Berdasarkan data BPS, konsumsi buah dan sayur 5 tahun terakhir mengalami penurunan, tingkat konsumsinya sekarang ini mencapai kurang dari 
setengah tingkat konsumsi yang direkomendasikan. Hasil penelitian di Kota Tarakan proporsi pengeluaran untuk pembelian sayur berada pada posisi kedua, namun hal tersebut tidak menandakan konsumsi sayur penduduk Kota Tarakan tinggi. $\mathrm{Hal}$ ini dikarenakan harga sayur yang cenderung mahal di Kota Tarakan. Berdasarkan data pada buletin ketahanan pangan Provinsi Kalimantan Utara berada pada posisi ke 33 dari 34 propvinsi untuk kategori konsumsi per gram sumber pangan sayur dan buah.

Konsumsi sumber pangan protein di Kota Tarakan cukup beragam setiap bulan dan setiap harinya. Anjuran konsumsi sumber pangan protein adalah 1 per 3 dari konsumsi nasi. Sumber protein pada penelitian ini adalah daging (sapi, kambing, kerbau dan unggas), Ikan (Ikan dan semua jenis makanan laut), susu, telur, kacang-kacangan. Total pengeluaran di kalkulasi dari bahan mentah ( segar dan diasinkan ) maupun makanan jadi seperti sosis dll. Proporsi pengeluaran protein tertinggi adalah daging 10,9 persen atau Rp. 158.680 per rumah tangga per bulan, jenis daging yang dikonsumsi mayoritas adalah daging ayam. Sedangkan proporsi pengeluaran sumber protein terendah adalah kacang - kacangan dengan proporsi 3,5\% atau Rp. 50.613 dengan jenis bahan pangannya adalah tahu dan tempe. Tahu dan tempe pada mayoritas responden dijadikan sebagai lauk pendamping, hal ini dikarenakan harganya yang relative murah sehingga dapat dijangkau berbagai kalangan.

Berdasarkan penjabaran di atas pengeluaran pangan dapat mengidentifikasikan, konsumsi pangan masyarakat di Kota Tarakan cukup beragam berdasarkan jumlah, kualitas dan variannya. Diversifikasi pangan sumber protein sangat beragam namun diersifikasi pangan sumber karbohidrat yang perlu dikaji karena masih tingginya pengeluaran akan sumber karbohidrat beras.

\section{Tingkat Diversifikasi Pangan Rumah Tangga di Kota Tarakan}

Metode Skor Keragaman Makanan Rumah Tangga (HDDS) adalah salah satu metode yang digunakan untuk menentukan keragaman konsumsi pangan rumah tangga. Instrumen sederhana ini diperkenalkan oleh Badan Pembangunan Internasional Amerika Serikat (USAID) melalui proyek Bantuan Teknis Pangan dan Gizi (FANTA), HDDS lebih lanjut dikembangkan oleh Organisasi Pangan dan Pertanian (FAO). Pada dasarnya HDDS mencerminkan kemampuan ekonomi rumah tangga untuk memperoleh berbagai tipe bahan makanan. Karena kualitas makanan yang dikonsumsi dilihat dari keragaman makanan. Dalam perhitungannya HDDS menggunakan 12 kelompok makanan diantaranya : Padi-padian, umbi-umbian, sayuran, buah-buahan, daging, unggas, telur, ikan dan makanan laut, kacangkacangan, susu dan produk susu, minyak / lemak, gula / madu, bumbu rempah.

Data konsumsi pangan rumah tangga dikumpulkan dengan menggunakan kuesioner recall 1 x 24 jam. Recall (mengingat kembali) digunakan untuk menilai kualitas makanan rumah tangga dalam metode HDDS adalah untuk lebih mengurangi kesalahan dalam pengukuran praktis, dan penggunaan jangka waktu $1 \times 24$ jam biasa digunakan dalam penelitian kualitas konsumsi makanan seperti yang dilakukan oleh (Savy M, Prevel YM, Sawadogo P, Kameli Y, 2005); Steyn et al. (2006)(Styen NP, Nel JH, Nantel G, Kennedy G, 2006);(Arimond, 2010); (Melani, 2014); (Rahajeng, 2015).

Berdasarkan gambar 2 , skor keragaman makanan rumah tangga (HDDS) 60 persen berada pada kategori tinggi, yang berarti mayoritas responden memiliki tingkat keragaman pangan yang tinggi atau mengkonsumsi lebih dari 6 jenis sumber pangan dalam sehari. Hasil skor ini sejalan dengan penelitian (Rahajeng, 2015) yang melakukan penelitian di Kota Palembang dengan tiga kategori pendapatan, pada pendapatan rendah nilai HDDS $70 \%$ pada kategori tinggi sedangkan pada pendapatan tinggi nilai HDDS $100 \%$ pada kategori tinggi. Namun hasil tersebut berbeda dengan penelitian (Adewumi \& Animashaun, 2013) yang menunjukkan hal tersebut HDD mendapat skor lebih rendah pada rumah tangga miskin di Nigeria. 
JURNAL BORNEO SAINTEK

Volume 1, Nomor 1, April 2020

e-ISSN 2599-3313

P-ISSN 2615-434X

\section{Household Dietry Diversity} Score

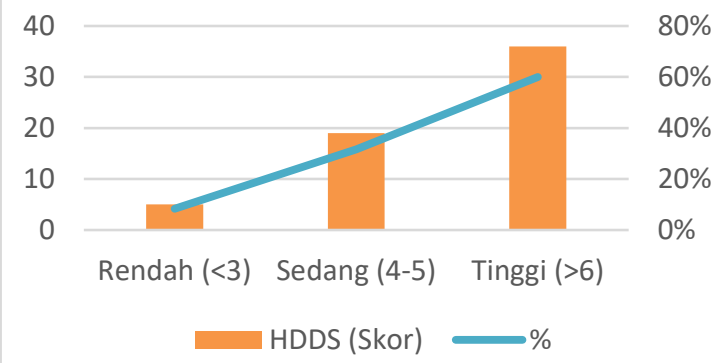

Gambar 2 . Nilai Skor Keragaman Konsumsi Pangan Rumah Tangga Kota

Tarakan 2020

Tingginya keragaman konsumsi pangan di Kota Tarakan ternyata didukung oleh akses fisik yang mudah ke beberapa kelompok makanan, seperti beras, sayuran, dan ikan. Jika dilihat sebaran rumah tangga contoh menurut masing-masing kelompok pangan HDDS, sebagian besar rumah tangga contoh mengonsumsi pangan beras $(100 \%)$, sayursayuran $(93 \%)$, sumber protein yang paling banyak dikonsumsi adalah ikan (70\%).(Gambar 3) hal ini dikarenakan mudah dan murah dalam mengakses ikan dibandingkan sumber protein lainnya. Konsumsi makanan untuk beberapa kelompok makanan tetap rendah. Ini dianggap karena keterbatasan akses ekonomi masyarakat untuk membeli kelompok makanan ini dan kurangnya masyarakat pengetahuan tentang pangan bergizi, variatif, dan seimbang.
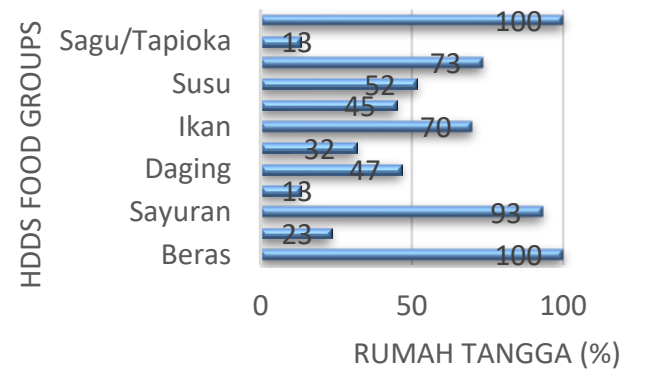

\section{DAFTAR PUSTAKA}

Adewumi, M. O., \& Animashaun, J. O. (2013). Households' dietary diversity, farm income and technical efficiency correlates: Empirical evidence from small-scale farming households in nigeria. Agris On-Line Papers in Economics and Informatics, 5(4), 3-11.

Ariani, M., Gatoet, H., Hardono, S., Tonny, S.,
Available online at www.jurnal.borneo.ac.id

Halaman 63-72

\section{Gambar 3 . Konsumsi Pangan Rumah Tangga Berdasarkan Kelompok Pangan di Kota Tarakan 2020}

\begin{abstract}
Kesimpulan
Produksi padi di Kota Tarakan cenderung mengalami penurunan, sedangkan produksi ubi kayu dan ubi jalar menunjukkan tren meningkat yang mengindikasi potensi diversifikasi produksi pangan di Kota tarakan. Secara garis besar pola diversifikasi konsumsi pangan masyarakat di Kota Tarakan cukup beragam berdasarkan jumlah, kualitas dan variannya, hal ini ditunjukkan dari pengeluaran pangan sumber protein yang beragam. Namun diversifikasi pangan sumber karbohidrat yang perlu dikaji karena masih tingginya pengeluaran akan sumber karbohidrat beras. Tingkat diversifikasi konsumsi pangan di Kota Tarakan berdasarkan nilai skor keragaman pangan rumah tangga (HDDS) berada pada kategori tinggi yaitu telah mengkonsumsi lebih dari enam jenis sumber pangan dalam sehari.
\end{abstract}

\section{Ucapan Terima Kasih}

Peneliti mengucapkan terimakasih kepada Unviersitas Borneo Tarakan atas sumber dana DIPA/PNBP sehingga penelitian ini dapat dilaksanakan. Peneliti juga mengucapkan terimakasih kepada Badan Pusat statistik Kota Tarakan, Fakultas Pertanian dan Jurusan Agribisnis Uniersitas Borneo Tarakan yang telah mendukung dan membantu dalam memberikan data maupun informasi untuk tujuan penelitian. 
Indicators Predict Micronutrient Adequacy Of Women's Diets In 5 Diverse, ResourcePoor Settings. J Nutr 140: 2059-2069.

BPS. (2019). Kota Tarakan Dalam Angka 2019.

FAO. (2013). Guidelines For Measuring Household And Individual Dietary Diversity. Roma (IT): FAO.

Harini, R., Ariani, R. D., Supriyati, S., \& Satriagasa, M. C. (2019). Analisis Luas Lahan Pertanian Terhadap Produksi Padi Di Kalimantan Utara. Jurnal Kawistara, 9(1), 15.

https://doi.org/10.22146/kawistara.38755

Melani, V. (2014). Validasi Household Dietary Diversity Score (HDDS) Sebagai Metode Alternatif Dalam Mengidentifikasi Rumah Tangga Rawan Pangan Di Wilayah.

Rahajeng, G. Y. (2015). The Effect Of Household Characteristics At Different Level of Incomes On Food Consumption Diversification In Palembang. Sriwijaya University.

Saputri, R., Lestari, L. A., \& Susilo, J. (2016). Pola konsumsi pangan dan tingkat ketahanan pangan rumah tangga di Kabupaten Kampar Provinsi Riau. Jurnal Gizi Klinik Indonesia, 12(3), 123. https://doi.org/10.22146/ijcn.23110

Savy M, Prevel YM, Sawadogo P, Kameli Y, D. F. (2005). Use Of Variety/Diversity Scores For Diet Quality Measurement: Relation With Nutritional Status Of Women In A Rural Area In Burkina Faso. Europ J Clin Nutr 59: 703716.

Styen NP, Nel JH, Nantel G, Kennedy G, L. D. (2006). Food Variety And Dietary Diversity Scores In Children: Are They Good Indicators Of Dietary Adequacy. Pub Health Nutr 9(5):644-50.

SUSENAS. (2019). Ringkasan Eksekutif Pengeluaran dan Konsumsi Penduduk Indonesia 2019. In Badan Pusat Statistik (Vol. 14, Issue 2). https://doi.org/10.15578/segara.v14i2.747 9

Swindale A, B. P. (2005). Household Dietary Diversity Score (HDDS) For Measurement Of Household Food Access: Indicator Guide. Washington (US): FANTA AED. 